\title{
Diagnosis and recommendations for management of trees and shrubs in green squares in Warsaw based on research on fungal diseases
}

\author{
Kinga Kimic $^{1}$ (D) Ewa Mirzwa-Mróz ${ }^{2}$ (D) $\cdot$ Marek S. Szyndel $^{2}$ D
}

Received: 30 January 2021 / Accepted: 20 January 2022 / Published online: 6 February 2022

(c) The Author(s) 2022

\begin{abstract}
Key message Comprehensive management of urban greenery is a key approach to control fungal diseases of trees and shrubs to avoid the deterioration in their health status.

Abstract Preliminary investigations on the health status related to fungal diseases of trees and shrubs growing in four green squares in Warsaw were conducted in 2017-2019. The examined plants were affected by diseases that are commonly identified in urban greenery, e.g., powdery mildew (causal agents: Sawadaea tulasnei, S. bicornis, Podosphaera leucotricha, Podosphaera sp., Erysiphe alphitoides, E. magnifica, E. berberidis, E. flexuosa and E. adunca), rusts (Gymnosporangium sabinae, Melampsora laricis-populina), apple scab (Venturia inaequalis), tar spot of maple (Rhytisma acerinum), and oyster mushroom (Pleurotus ostreatus). The causal agents of the diseases were identified based on their morphological (macro- and microscopic) features. Preventing and managing fungal plant diseases and reduction of their effects are the key tasks in conscious management of urban greenery. To address this issue, the study presents basic guidelines based on the application of various recommended actions and good practices, which constitute a comprehensive and sustainable strategy for integrated protection of trees and shrubs against these diseases. The implementation of the strategy for complex management of urban greenery is a crucial measure aimed at maintenance of a high health status of urban plants.
\end{abstract}

Keywords Trees and shrubs · Urban greenery $\cdot$ Management of urban forest $\cdot$ Woody plant diseases $\cdot$ Fungal diseases

\section{Introduction}

In recent years, growing emphasis has been placed on increasing the area and maintenance of urban greenery. Green areas provide a wide range of environmental, social, and economic benefits to city inhabitants (Johnston and

Kinga Kimic

kinga_kimic@sggw.edu.pl

Ewa Mirzwa-Mróz

ewa_mirzwa_mroz@sggw.edu.pl

Marek S. Szyndel

marek_szyndel@sggw.edu.pl

1 Department of Landscape Architecture, Institute of Environmental Engineering, Warsaw University of Life Sciences-SGGW, Nowoursynowska Street 159, 02-776 Warsaw, Poland

2 Division of Plant Pathology, Department of Plant Protection, Institute of Horticultural Sciences, Warsaw University of Life Sciences-SGGW, Nowoursynowska Street 159, 02-776 Warsaw, Poland
Hirons 2014). Even small green squares, thanks to the presence of healthy plants, co-create a complex system of natural elements supporting environmental processes in urbanized areas (Tzoulas et al. 2007; Shi and Woolley 2014; Karade et al. 2017). They become one of the main factors counteracting the negative effects of climate change, such as urban heat island (Livesley et al. 2016; Werbin et al. 2020) and eliminate pollution (Donovan 2017). The vegetation of green squares is a valuable natural resource with a significant contribution to biodiversity in cities (Alvey 2006; Schlaepfer 2018; Schlaepfer et al. 2020) resulted from the taxonomic diversity of plants as well as the support of other plant and animal species and their mutual interactions (Kowarik 2011). Appropriately maintained trees and shrubs are particularly valuable as the basic elements in the urban greenery structure (Stagoll et al. 2012), usually composed of many native and alien ornamental species and varieties (Nielsen et al. 2014). The role of fruit trees and shrubs is also being increasingly appreciated (Kimic 2019, 2021; Lisandru et al. 2016), as they are melliferous species providing food for insect pollinators (Hausmann et al. 2016). 
Urban squares, which are public green spaces situated in or close to residential areas (Wysmułek et al. 2020), encourage people to visit them (Baur and Tynon 2010; Shanahan et al. 2015) and are gaining more importance as recreational grounds (Baur and Tynon 2010; Peschardt et al. 2012; Baur 2018). They contribute to the improvement of the physical health of city residents, as they invite to spent more time outdoor and ensure place for recreation (Aldous 2007; Baur and Tynon 2010; Pearlmutter et al. 2017), and at the same time promote various social interactions (Kazmierczak 2013). Green areas ensure contact with nature in cities (Kuo 2015; Ngiam et al. 2017; Wolf et al. 2020), which additionally improves public mental health and wellbeing (Bowler et al. 2010; Grahn and Stigsdotter 2010; Donovan 2017; Zölch et al. 2019), increases life satisfaction (Berman et al. 2012), reduces negative thinking, eliminates stress, and even alleviates symptoms of depression (Ulrich et al. 1991; Berman et al. 2012; Berto 2014). Mature and healthy trees and shrubs have high ornamental value and are important elements increasing the attractiveness of the city landscape (Troy et al. 2016), which is positively perceived by society (Tyrväinen et al. 2005). Additionally, well-maintained plants are important to ensure the safety of public greenery users (Suchocka and Kimic 2019).

Trees and shrubs, which support a number of urban ecosystem services, have a direct effect on the economic value of greenery (Seth 2003; Nowak and Dwyer 2007; Chen and Jim 2008). Failure to consider the multiple benefits provided by trees and shrubs to the functioning of cities and to their inhabitants may result in underinvestment in urban greenery (Hauer et al. 2015; Koeser et al. 2016; Donovan 2017). Modern management in that context should focus on many aspects of planning, design, maintenance, and protection as well as conservation of existing green spaces. Although the knowledge in this field has expanded considerably over the last few decades (Johnston and Hirons 2014), likewise the public awareness of the role of urban greenery (Zürcher 2017), management of urban trees and shrubs is still a huge challenge for researchers, urban greenery professionals, and city authorities due to the growing threats to green areas (Feltynowski et al. 2018).

All the aforementioned values constitute strong arguments for preservation of the good health status of urban green spaces (Baur and Tynon 2010; Pearlmutter et al. 2017). Unfortunately, it is predicted that many native tree and shrub species are likely to exhibit increasing death rates as a result of the deteriorating conditions of the urban environment, e.g., the rising air, soil, and water pollution and the escalation of extreme events as torrential rainfalls, periods of water scarcity, or thermal stress caused by periodic high temperatures and prolonged drought. These changes are associated with the progressive negative climate changes and the effects of the urban heat island, which is currently recognized as the leading cause of disturbance of urban plants (Aitken et al. 2008; Tubby and Webber 2010). Weakened trees and shrubs become more susceptible to infections by various pathogens, which reproduce and spread causing infections and further deterioration of plants' health and their esthetic and functional values, reduction of growth rate, dieback of shoots and buds, damage to the bark, and consequent death (Marçais and Desprez-Loustau 2014). Currently, fungi are one of the most common agents of plant diseases in urban green areas, i.e., necrosis, wilt, spots, canker, and rot of various plant parts, causing various types of damage with typical symptoms. Fungal diseases generate a substantial increase in the costs of maintenance of urban greenery related to their control and removal of dead parts or even entire plants. Additionally, they raise concerns about the future of plant populations in urban green areas. Changes occurring in the ecological conditions of the urban environment have an impact on the presence and intensification of the activity of plant pathogens (Tello et al. 2005). In light of the expected global climate changes, there is a need for thoughtful management of both newly created and already existing urban green areas and their plants in the coming years (Tubby and Webber 2010). In particular, the management should be compatible with the global strategies for sustainable development, as the benefits of the presence of trees and shrubs in cities can help fulfill as many as 15 of the 17 UN 2030 Sustainable Development Goals (Turner-Skoff and Cavender 2019).

Decisions related to the management of urban greenery are crucial for the maintenance of plants and the overall urban resilience. However, in many cases, e.g., in Warsaw, there are limited numbers of investigations of fungal diseases affecting plants in urban green areas. Therefore, the aim of the study was to conduct preliminary analysis of the health of trees and shrubs growing in four squares in this city to detect the presence of fungal diseases. Since the indications for greenery management in this field are highly limited (Standardy Kształtowania Zieleni Warszawy 2016), the additional goal of the study was also to formulate main guidelines based on the various verified and recommended actions and good practices that constitute a comprehensive and sustainable strategy for integrated protection of trees and shrubs against fungal diseases. This is crucial for the health of plants growing in urban green squares.

\section{Materials and methods}

\section{Plant materials}

In 2017-2019, preliminary studies of the health status of trees and shrubs growing in four green squares located in the central districts of Warsaw were carried out: 
- Siberian Square located between Chłodna and Krochmalna Streets in Wola district (Square A),

- Sue Ryder Square located in Ochota district, between Jan Dantyszek, Andrzej Krzycki, and Mikołaj Rej Streets (Square B),

- Mieczysław Dawid Apfelbaum Square located in Wola district, between Pawia, Smocza, and Dzielna Streets (Square C),

- Jan Jura-Gorzechowski Square located in Wola district, between Jan Paweł II Alley, Smocza, and Dzielna Streets (Square D).

The trees and shrubs were inventoried during field work carried out in summer 2017. A detailed list of the identified tree and shrub species with the Latin names of the species and variety (if present) is provided in the tables separately for each square with assignment of a separate number to individual trees and shrubs or groups of shrubs. The location of the identified plants in each of the green squares has been marked on a separate base map prepared in the scale of 1:500. The basic dendrometric plant parameters were measured: the trunk circumference at a height of $130 \mathrm{~cm}$, the diameter of the crown, and the approximate height of trees and shrubs. The diameters and height of smaller shrubs were measured, and the surface area of shrub groups with the number of plants of a given species and their average height were determined (the data are held by the authors but not shown in this paper). This documentation served as the input material for identification of plants infected with fungal diseases. The plants (stems, shoots, leaves, fruits) were inspected for the presence of symptoms of diseases and etiological signs of pathogens. The investigations were carried out in the four seasons: autumn, winter, spring, and summer. The names of the host plants (trees and shrubs) followed the nomenclature proposed by Dolatowski and Seneta (2009). The names of the pathogens were determined based on the Index Fungorum 2017 and 2020 (the global fungal nomenclature) and the Mycobank 2017 and 2020 (an on-line database aimed as a service to the mycological and scientific community).

\section{Mycological investigations}

The mycological investigations were carried out in 2017-2019 in the Section of Plant Pathology, Warsaw University of Life Sciences-SGGW. Samples of leaves, shoots, or fruits were taken from trees and shrubs with visible symptoms of diseases.

Pathogens were identified based on their morphology using mycological keys and scientific publications (Braun 2011; Braun and Cook 2012; Majewski 1977, 1979; Marcinkowska 2012). The collected plant material was examined under an SZ11 stereoscopic microscope (Olympus). Microscopic slides were analyzed using a BX50 light microscope (Olympus). Photographs of individual fungal structures (approx. 30) were taken with the DP71 camera (Olympus) and the measurements were made in Cell F software (Olympus). Additionally, individual objects in the square were photographed.

\section{Results}

In total, 889 plants were inventoried in the four Warsaw squares during the 2017-2019 investigations. Fungal diseases were identified on the following 111 plants:

- 68 infected plants of the 225 specimens inventoried in Siberian Square (Square A)

- 5 infected plants of the 222 specimens inventoried in Sue Ryder Square (Square B)

- 23 infected plants of the 203 specimens inventoried in Mieczysław Dawid Apfelbaum Square (Square C)

- 15 infected plants of the 239 specimens inventoried in Jan Jura-Gorzechowski Square (Square D)

Powdery mildews were the largest group, as they were noted on 85 plants representing eight different tree and shrub species (Table 1). Symptoms caused by the fungus Sawadaea tulasnei (order Erysiphales) (Fig. 1 Bb, Ca, Fig. 2 Ia, $\mathrm{Ib}$ ) were observed on A. platanoides in Square A (on 100\% of plants representing this species) and in Square D (21\% of this species) and on Acer tataricum ssp. ginnala (Fig. 1 Cc) in Square C (47\% of this species). The powdery mildew disease caused by S. bicornis (Fig. 1 Aa) was identified on one specimen of Acer negundo tree growing in Square B (100\% of plants of this species). The anamorphs of both identified fungi (S. tulasnei and S. bicornis) produced catenescent conidia (Euoidium type). Short conidiophores were observed to bear conidial chains. Macro- and micro conidiophores were observed. There were many ellipsoid-obovoid asci in the chasmothecia, usually with eight hyaline ascospores. The appendages were mainly simple and some were dichotomously branched. The appendages in S. bicornis were mainly branched, and some were trichotomously branched. The apices were tightly uncinate to circinate.

The symptoms of Erysiphe alphitoides (Fig. $1 \mathrm{Ka}$ ) as the causal agent of powdery mildew were identified on one tree of Quercus robur L. 'Fastigiata' growing in Square B (100\% of plants of this species). The fungus E. magnifica (Fig. 1 Fa, Fig. 2 Da, Db) was observed on all 5 magnolia trees growing in Square C (100\% of plants). At the same time E. berberidis (Fig. $1 \mathrm{Ea}, \mathrm{Eb}$, Fig. $2 \mathrm{Ba}, \mathrm{Bb}, \mathrm{Bc}$ ) was identified on all Berberis vulgaris 'Atropurpurea' plants in Square A and on $8 \%$ of B. vulgaris plants in Square D. 
Table 1 List of representatives of trees and shrubs infected by fungal pathogens in selected green squares in Warsaw (2017-2019)

\begin{tabular}{|c|c|c|c|c|c|c|c|c|c|}
\hline \multirow[t]{2}{*}{$\mathrm{Nr}$} & \multirow[t]{2}{*}{ Plant Latin name } & \multirow[t]{2}{*}{$\begin{array}{l}\text { Plant com- } \\
\text { mon name }\end{array}$} & \multicolumn{2}{|c|}{$\begin{array}{l}\text { Cross-referenced with } \\
\text { photos: }\end{array}$} & \multirow{2}{*}{$\begin{array}{l}\text { Pathogen } \\
\text { (Taxonomic } \\
\text { name) }\end{array}$} & \multirow[t]{2}{*}{ Disease } & \multirow[t]{2}{*}{$\begin{array}{l}\text { Symptoms } \\
\text { visible on: }\end{array}$} & \multirow{2}{*}{$\begin{array}{l}\text { Number } \\
\text { of infected } \\
\text { plants / Total } \\
\text { plant species }\end{array}$} & \multirow{2}{*}{$\begin{array}{l}\% \text { of infected } \\
\text { plants of each } \\
\text { species }\end{array}$} \\
\hline & & & $\begin{array}{l}\text { Symp- } \\
\text { toms } \\
\text { (Fig. 1) }\end{array}$ & $\begin{array}{l}\text { Mycological } \\
\text { structures } \\
\text { (Fig. 2) }\end{array}$ & & & & & \\
\hline \multicolumn{10}{|c|}{ Square A. -Siberian Square } \\
\hline 1 & Acer platanoides $\mathrm{L}$ & $\begin{array}{r}\text { Norway } \\
\text { maple }\end{array}$ & $\mathrm{Ba}$ & - & $\begin{array}{l}\text { Rhytisma } \\
\text { acerinum } \\
\text { (Pers.) Fr }\end{array}$ & Tar Spot & Leaves & $4 / 4$ & 100 \\
\hline 2 & Acer platanoides $\mathrm{L}$ & $\begin{array}{r}\text { Norway } \\
\text { maple }\end{array}$ & $\mathrm{Bb}$ & $\mathrm{Ia}, \mathrm{Ib}$ & $\begin{array}{c}\text { Sawadaea } \\
\text { tulasnei } \\
\text { (Fuckel) } \\
\text { Homma }\end{array}$ & $\begin{array}{l}\text { Maple } \\
\text { Powdery } \\
\text { Mildew }\end{array}$ & Leaves & $4 / 4$ & 100 \\
\hline 3 & $\begin{array}{l}\text { Berberis vulgaris } \\
\text { L.'Atropurpurea' }\end{array}$ & $\begin{array}{l}\text { European } \\
\text { barberry }\end{array}$ & $\mathrm{Ea}, \mathrm{Eb}$ & $\mathrm{Ba}, \mathrm{Bb}, \mathrm{Bc}$ & $\begin{array}{l}\text { Erysiphe } \\
\text { berberidis } \\
\text { DC }\end{array}$ & $\begin{array}{l}\text { Barberry } \\
\text { Powdery } \\
\text { Mildew }\end{array}$ & $\begin{array}{l}\text { Leaves, } \\
\text { shoots, } \\
\text { fruits }\end{array}$ & $20 / 20$ & 100 \\
\hline 4 & $\begin{array}{l}\text { Malus x purpurea } \\
\text { Rehd.'Ola' }\end{array}$ & Apple-tree & $\mathrm{Gb}$ & - & $\begin{array}{l}\text { Venturia } \\
\text { inaequalis } \\
\text { (Cooke) G. } \\
\text { Winter }\end{array}$ & Apple Scab & Leaves, fruits & $39 / 40$ & 97,5 \\
\hline 5 & $\begin{array}{l}\text { Malus x purpurea } \\
\text { Rehd.'Ola' }\end{array}$ & Apple-tree & $\mathrm{Ga}$ & - & $\begin{array}{l}\text { Podosphaera } \\
\text { leucotricha } \\
\text { (Ellis et } \\
\text { Everh.) E.S. } \\
\text { Salmon }\end{array}$ & $\begin{array}{l}\text { Apple } \\
\text { Powdery } \\
\text { Mildew }\end{array}$ & $\begin{array}{l}\text { Leaves, } \\
\text { shoots }\end{array}$ & $25 / 40$ & 62,5 \\
\hline 6 & $\begin{array}{l}\text { Populus nigra } \mathrm{L} \\
\text { 'Italica' }\end{array}$ & Black poplar & Ia & $\mathrm{Aa}$ & $\begin{array}{l}\text { Erysiphe } \\
\text { adunca } \\
\text { (Wallr.) Fr }\end{array}$ & $\begin{array}{l}\text { Poplar } \\
\text { Powdery } \\
\text { Mildew }\end{array}$ & Leaves & $5 / 5$ & 100 \\
\hline 7 & $\begin{array}{l}\text { Populus nigra } \\
\text { L.'Italica' }\end{array}$ & Black poplar & $\mathrm{Ib}$ & $\mathrm{Fa}$ & $\begin{array}{l}\text { Melampsora } \\
\text { laricis- } \\
\text { populina } \\
\text { Kleb }\end{array}$ & Poplar Rust & $\begin{array}{l}\text { Leaves, } \\
\text { shoots }\end{array}$ & $5 / 5$ & 100 \\
\hline 8 & $\begin{array}{l}\text { Populus nigra } \\
\text { L.'Italica' }\end{array}$ & Black poplar & Ic & - & $\begin{array}{l}\text { Pleurotus } \\
\text { ostreatus } \\
\text { (Jacq.) P. } \\
\text { Kumm }\end{array}$ & $\begin{array}{l}\text { White Flacy } \\
\text { Sapwood } \\
\text { Rot }\end{array}$ & Trunk & $1 / 5$ & 20 \\
\hline \multicolumn{10}{|c|}{ Square B. -Sue Ryder Square } \\
\hline 1 & Acer negundo $\mathrm{L}$ & $\begin{array}{l}\text { Box elder, } \\
\text { Boxelder } \\
\text { maple }\end{array}$ & $\mathrm{Aa}$ & - & $\begin{array}{c}\text { Sawadaea } \\
\text { bicornis } \\
\text { (Wallr.) } \\
\text { Homma }\end{array}$ & $\begin{array}{l}\text { Powdery } \\
\text { Mildew }\end{array}$ & Leaves & $1 / 1$ & 100 \\
\hline 2 & $\begin{array}{l}\text { Aesculus hip- } \\
\text { pocastanum } \mathrm{L}\end{array}$ & $\begin{array}{l}\text { Horse chest- } \\
\text { nut }\end{array}$ & $\mathrm{Da}$ & $\mathrm{Ca}, \mathrm{Cb}$ & $\begin{array}{l}\text { Erysiphe } \\
\text { flexuosa } \\
\text { (Peck) U. } \\
\text { Braun \& S. } \\
\text { Takam }\end{array}$ & $\begin{array}{l}\text { Horse } \\
\text { Chestnut } \\
\text { Powdery } \\
\text { Mildew }\end{array}$ & Leaves & $1 / 8$ & 12,5 \\
\hline 3 & $\begin{array}{l}\text { Quercus robur } \mathrm{L} . \\
\text { 'Fastigiata' }\end{array}$ & $\begin{array}{l}\text { Skyrocket } \\
\text { English oak }\end{array}$ & $\mathrm{Ka}$ & - & $\begin{array}{l}\text { Erysiphe } \\
\text { alphitoides } \\
\text { (Griffon \& } \\
\text { Maubl.) U. } \\
\text { Braun \& S. } \\
\text { Takam }\end{array}$ & $\begin{array}{l}\text { Powdery Oak } \\
\text { Mildew }\end{array}$ & Leaves & $1 / 1$ & 100 \\
\hline 4 & Malus sp. & Apple-tree & $\mathrm{Ha}$ & $\mathrm{Ga}$ & $\begin{array}{l}\text { Podosphaera } \\
\text { leucotricha } \\
\text { (Ellis et } \\
\text { Everh.) E.S. } \\
\text { Salmon }\end{array}$ & $\begin{array}{l}\text { Apple } \\
\text { Powdery } \\
\text { Mildew }\end{array}$ & $\begin{array}{l}\text { Leaves, } \\
\text { shoots }\end{array}$ & $1 / 2$ & 50 \\
\hline
\end{tabular}


Table 1 (continued)

\begin{tabular}{|c|c|c|c|c|c|c|c|c|c|}
\hline \multirow[t]{2}{*}{$\mathrm{Nr}$} & \multirow[t]{2}{*}{ Plant Latin name } & \multirow[t]{2}{*}{$\begin{array}{l}\text { Plant com- } \\
\text { mon name }\end{array}$} & \multicolumn{2}{|c|}{$\begin{array}{l}\text { Cross-referenced with } \\
\text { photos: }\end{array}$} & \multirow{2}{*}{$\begin{array}{l}\text { Pathogen } \\
\text { (Taxonomic } \\
\text { name) }\end{array}$} & \multirow[t]{2}{*}{ Disease } & \multirow[t]{2}{*}{$\begin{array}{l}\text { Symptoms } \\
\text { visible on: }\end{array}$} & \multirow{2}{*}{$\begin{array}{l}\text { Number } \\
\text { of infected } \\
\text { plants / Total } \\
\text { plant species }\end{array}$} & \multirow{2}{*}{$\begin{array}{l}\% \text { of infected } \\
\text { plants of each } \\
\text { species }\end{array}$} \\
\hline & & & $\begin{array}{l}\text { Symp- } \\
\text { toms } \\
\text { (Fig. 1) }\end{array}$ & $\begin{array}{l}\text { Mycological } \\
\text { structures } \\
\text { (Fig. 2) }\end{array}$ & & & & & \\
\hline 5 & Malus sp. & Apple-tree & $\mathrm{Hb}$ & - & $\begin{array}{l}\text { Venturia } \\
\text { inaequalis } \\
\text { (Cooke) G. } \\
\text { Winter }\end{array}$ & Apple Scab & Leaves, fruits & $1 / 2$ & 50 \\
\hline \multicolumn{10}{|c|}{ Square C. -Mieczysław Dawid Apfelbaum Square } \\
\hline 1 & Magnolia sp. & Magnolia & $\mathrm{Fa}$ & $\mathrm{Da}, \mathrm{Db}$ & $\begin{array}{l}\text { Erysiphe } \\
\text { magnifica } \\
\text { (U. Braun) U. } \\
\text { Braun \& S. } \\
\text { Takam }\end{array}$ & $\begin{array}{l}\text { Powdery } \\
\text { Mildew }\end{array}$ & Leaves & $5 / 5$ & 100 \\
\hline 2 & $\begin{array}{l}\text { Acer tataricum } \mathrm{L} \text {. } \\
\text { ssp. ginnala }\end{array}$ & Amur maple & $\mathrm{Ca}$ & - & $\begin{array}{c}\text { Sawadaea } \\
\text { tulasneli } \\
\text { (Fuckel) } \\
\text { Homma }\end{array}$ & $\begin{array}{l}\text { Maple } \\
\text { Powdery } \\
\text { Mildew }\end{array}$ & Leaves & $8 / 17$ & 47 \\
\hline 3 & Pyrus communis L & $\begin{array}{l}\text { European } \\
\text { pear, Com- } \\
\text { mon pear }\end{array}$ & $\mathrm{Ja}$ & $\mathrm{Ea}, \mathrm{Eb}$ & $\begin{array}{l}\text { Gymnospo- } \\
\text { rangium } \\
\text { sabinae } \\
\text { (Dicks.) G. } \\
\text { Winter }\end{array}$ & Pear Rust & $\begin{array}{l}\text { Leaves, } \\
\text { shoots }\end{array}$ & $10 / 10$ & 100 \\
\hline 4 & $\begin{array}{l}\text { Acer tataricum } \mathrm{L} \text {. } \\
\text { ssp. ginnala }\end{array}$ & Amur maple & $\mathrm{Cb}$ & - & $\begin{array}{l}\text { Pleurotus } \\
\text { ostreatus } \\
\text { (Jacq.) P. } \\
\text { Kumm }\end{array}$ & $\begin{array}{l}\text { White Flacy } \\
\text { Sapwood } \\
\text { Rot }\end{array}$ & Trunk & $1 / 17$ & 6 \\
\hline \multicolumn{10}{|c|}{ Square D. -Jan Jura-Gorzechowski Square } \\
\hline 1 & Acer platanoides $\mathrm{L}$ & $\begin{array}{l}\text { Norway } \\
\text { maple }\end{array}$ & $\mathrm{Bb}$ & $\mathrm{Ia}, \mathrm{Ib}$ & $\begin{array}{c}\text { Sawadaea } \\
\text { tulasnei } \\
\text { (Fuckel) } \\
\text { Homma }\end{array}$ & $\begin{array}{l}\text { Maple } \\
\text { Powdery } \\
\text { Mildew }\end{array}$ & Leaves & $5 / 24$ & 21 \\
\hline 2 & $\begin{array}{l}\text { Berberis vulgaris } \\
\text { L }\end{array}$ & $\begin{array}{l}\text { European } \\
\text { barberry }\end{array}$ & Ea, & $\mathrm{Ba}, \mathrm{Bb}, \mathrm{Bc}$ & $\begin{array}{l}\text { Erysiphe } \\
\text { berberidis } \\
\text { DC }\end{array}$ & $\begin{array}{l}\text { Barberry } \\
\text { Powdery } \\
\text { Mildew }\end{array}$ & $\begin{array}{l}\text { Leaves, } \\
\text { shoots }\end{array}$ & $7 / 91$ & 8 \\
\hline 3 & Spiraea japonica $L$ & $\begin{array}{l}\text { Japanese } \\
\text { meadow- } \\
\text { sweet }\end{array}$ & $\mathrm{La}$ & $\mathrm{Ha}$ & $\begin{array}{l}\text { Podosphaera } \\
\text { sp. }\end{array}$ & $\begin{array}{l}\text { Powdery } \\
\text { Mildew }\end{array}$ & Leaves & $3 / 3$ & 100 \\
\hline
\end{tabular}

Powdery mildews, such as E. alphitoides, E. magnifica, and $E$. berberidis, produced Pseudoidium-type anamorphs. In turn, their chasmothecia had several-fold dichotomously branched appendages. In each chasmothecium, there were several asci with colorless ovoid or ellipsoid ascospores. The other two species of powdery mildew with croziershaped secondary appendages, i.e., E. flexuosa observed on one specimen of Aesculus hippocastanum growing in Square B (12,5\% of those species) (Fig. 1 Da, Fig. 2 Ca, $\mathrm{Cb}$ ) and E. adunca identified on all trees of Populus nigra 'Italica' (Fig. 1 Ia, Fig. 2 Aa), also produced Pseudoidiumtype anamorphs and numerous asci in the chasmothecia. However, the chasmothecia in E. flexuosa had undulate helicoid secondary appendages with closely circinate tips, whereas E. adunca had a slightly circinate apex only.

Powdery mildew caused by Podosphaera leucotricha was observed on leaves of 62,5\% of apple trees (Malus sp.) growing in Square A (Fig. $1 \mathrm{Ga}$ ) and on $50 \%$ of this species growing in Square B (Fig. 1 Ha, Fig. 2 Ga). They were covered by a fine white coating formed by the mycelium, conidiophores, and conidia. The conidia were cylindrical-ellipsoidal and formed chains on short conidiophores (Euoidium type). As in the case of P. leucotricha observed on Malus sp., a similar type of conidial sporulation was observed on leaves of $100 \%$ of infected Spiraea japonica L. shrubs, which were covered by a white coating. Unfortunately, there were no chasmothecia of this pathogen in the coating. As shown by literature reports, 

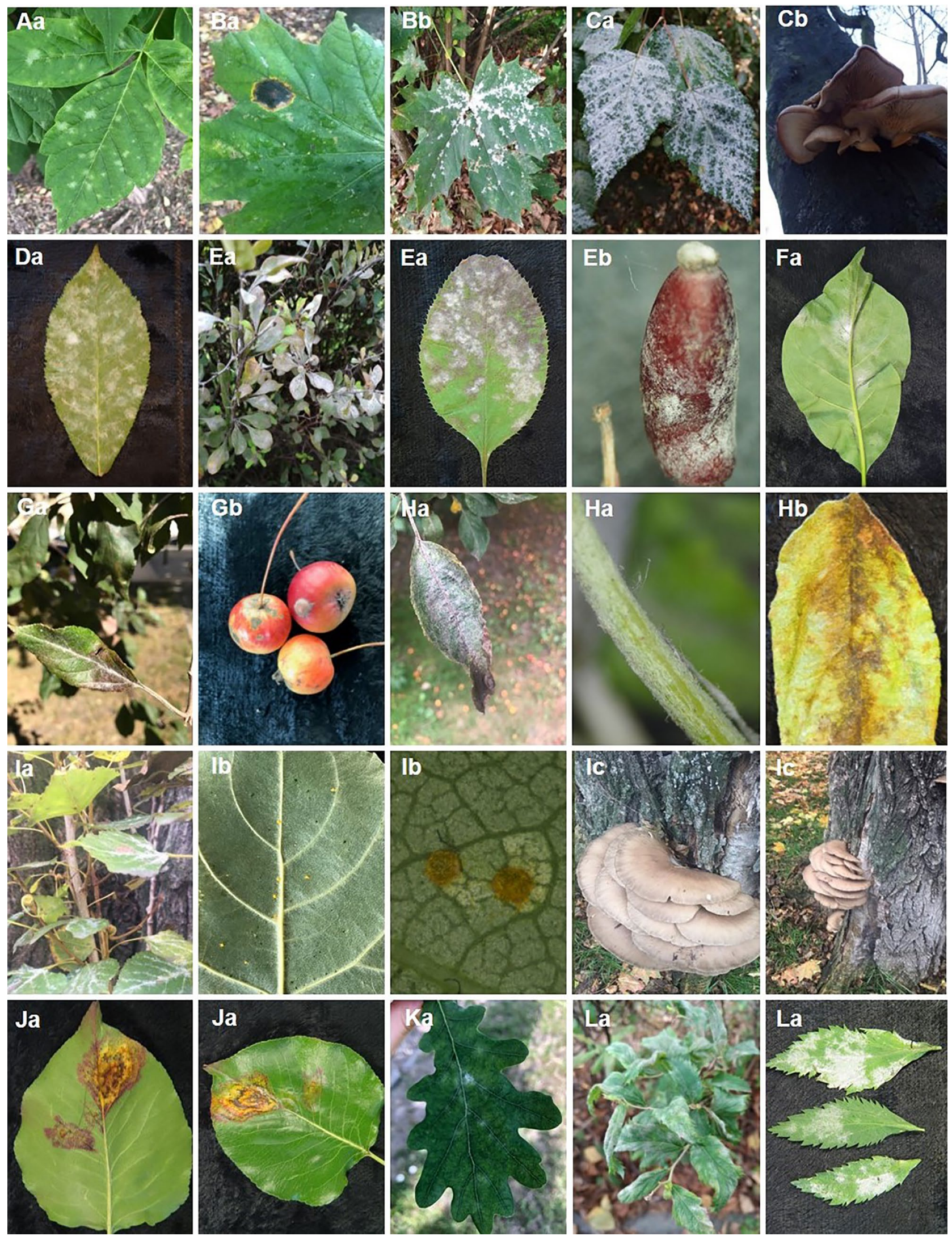
4Fig. 1 Disease symptoms caused by fungal pathogens on plant hosts examined during survey cross-referenced to the list of infected plants in Table 1. A Acer negundo L. (Aa- Sawadaea) (Phot. AB). B Acer platanoides L.: Ba Rhytisma (Phot. MŁ), Bb Sawadaea (Phot. AS). C Acer tataricum ssp. ginnala: Ca Sawadaea, Phot. JM), Cb Pleurotus (Phot. JM). D Aesculus hippocastanum L.: Da Erysiphe (Phot. EMM). E Berberis vulgaris L.'Atropurpurea': Ea (Phot. AS and EMM), Eb Erysiphe (Phot. EMM). F Magnolia sp.: Fa Erysiphe (Phot. EMM). G Malus x purpurea Rehd.'Ola': Ga Podosphaera (Phot. MŁ), Gb Venturia (Phot. EMM). H Malus sp.: Ha Podosphaera (Phot. AB), Hb Venturia (Phot. AB). I Populus nigra L.'Italica': Ia Erysiphe (Phot. MŁ), Ib Melampsora (Phot. EMM), Ic Pleurotus (Phot. MŁ). J Pyrus communis L: Ja Gymnosporangium (Phot. EMM). K Quercus robur L. 'Fastigiata': Ka Erysiphe (Phot. AB). L Spiraea japonica L.: La Podosphaera sp. (Phot. AS and EMM). (Authors of photographs: Ewa Mirzwa-Mróz (EMM), students: Marta Łukaszewska (MŁ), Aleksandra Borkowska (AB), Agata Skrzypczak (AS))

this species is mainly infected by powdery mildews from the Podosphaera genus (Braun and Cook 2012; Mieslerová et al. 2020); hence, the powdery mildew agent on S. japonica plants growing in square D was identified as Podosphaera sp.

The causal agent of apple scab, i.e., the fungus Venturia inaequalis (Pleosporales) with the anamorph stage Fusicladium pomi (Fr.) Lind (syn. Spilocaea pomi Fr.), was identified on various ornamental apple species and cultivars including 97.5\% of Malus x purpurea 'Ola' trees growing in Square A and $50 \%$ of Malus sp. trees from Square B. The disease symptoms were observed on leaves and fruits (Fig. $1 \mathrm{~Gb}, \mathrm{Hb}$ ). The leaves were covered by a brown-olive coating consisting of short conidiophores and pear-shaped conidia, while the fruits had small scab-like spots.

The other pathogens observed on other fruit trees (Pyrus communis) were the causal agents of rust diseases: pear rust caused by Gymnosporangium sabinae (100\% of trees representing this species) (Fig. $1 \mathrm{Ja}$, Fig. $2 \mathrm{Ea}, \mathrm{Eb}$ ) with orange-red spots with black spermogonia and Roestelia-type aecia (conical) developed underneath these spots. The poplar rust caused by the fungus Melampsora laricis-populina syn. Melampsora populi (Sowerby) M. Morelet were observed on $100 \%$ of $P$. nigra 'Italica' trees) (Fig. 1 Ib, Fig. 2 Fa).

Fruiting bodies of Pleurotus ostreatus were observed on only one specimen of Amur maple (A. tataricum) growing in square $\mathrm{C}$ and on the trunk of one tree of a Black poplar $(P$. nigra 'Italica' growing in Square A (Fig. $1 \mathrm{Cb}, \mathrm{Ic}$ ).

Leaves of the all Norway maples (Acer platanoides L.) growing in Square A had large dark spots (mycelial stroma) characteristic of the fungus Rhytisma acerinum, i.e., the cause of tar spot disease of maple leaves (Fig. $1 \mathrm{Ba}$ ). The disease commonly affects maples in urban green areas.

\section{Discussion}

\section{Occurrence of fungal diseases}

In the present study, powdery mildews were the most common pathogens as they had optimal conditions for development on plants growing in urban agglomerations (higher air temperature than that in non-urban areas and almost always sufficient humidity at the leaf blade surface-transpiration). They have been identified based on the anamorph type, characteristics of the teleomorph (shape of appendages on the chasmothecium, number of asci in the ascocarps, and partly the size of ascospores) (Braun and Cook 2012; Marcinkowska 2012; Mieslerová et al. 2020). Symptoms of powdery mildew by the fungus S. tulasnei (order Erysiphales) observed on A. platanoides and on A. tataricum ssp. ginnala included the mycelium developed mainly on the upper side of the leaves. The morphology and sizes of fungus structures (conidia, chasmothecia, appendages, asci, and ascospores) were similar to those described in literature (Braun and Cook 2012; Marcinkowska 2012; Mieslerová et al. 2020). In Poland, this pathogen was observed on the Norway maple by Kochman (1960) and Sucharzewska (2010). In a study carried out by Sucharzewska (2010), S. tulasnei developed abundantly on the Norway maple during a dry and warm summer. A similar situation was observed in the present study, i.e., the very high temperatures with little rainfall recorded during the growing season may explain the infection of $100 \%$ of $A$. platanoides trees in all the analyzed squares (A, B, C, and D), which are located virtually in the center of Warsaw.

The powdery mildew disease identified on Acer negundo trees was caused by S. bicornis, whose morphological features were consistent with literature data (Braun and Cook 2012; Kochman 1986; Mieslerová et al. 2020). The pathogen formed a fine white coating on both sides of the leaves, gradually covering their entire surface. In contrast to those observed in $S$. tulasnei, the appendages formed on the chasmothecia were 1-threefold branched (Kochman 1986; Heluta et al. 2016). This fungus (referred to as Uncinula bicornis (Wallr.) Lév.) was observed on $A$. negundo in Poland in 1999 (Dynowska et al. 1999).

Powdery mildew caused by P. leucotricha observed on many Malus sp. is the second-most common apple tree disease after scab (Cimanowski 1969). In our investigations, we did not observe the teleomorph of this pathogen. As demonstrated in literature, one globoid ascus with eight hyaline ascospores develops in each chasmothecium. Secondary appendages are stiff to flexuous, with mostly simple apices (Braun and Cook 2012; Marcinkowska 2012). In Poland, as shown by Cimanowski (1969), the perfect 

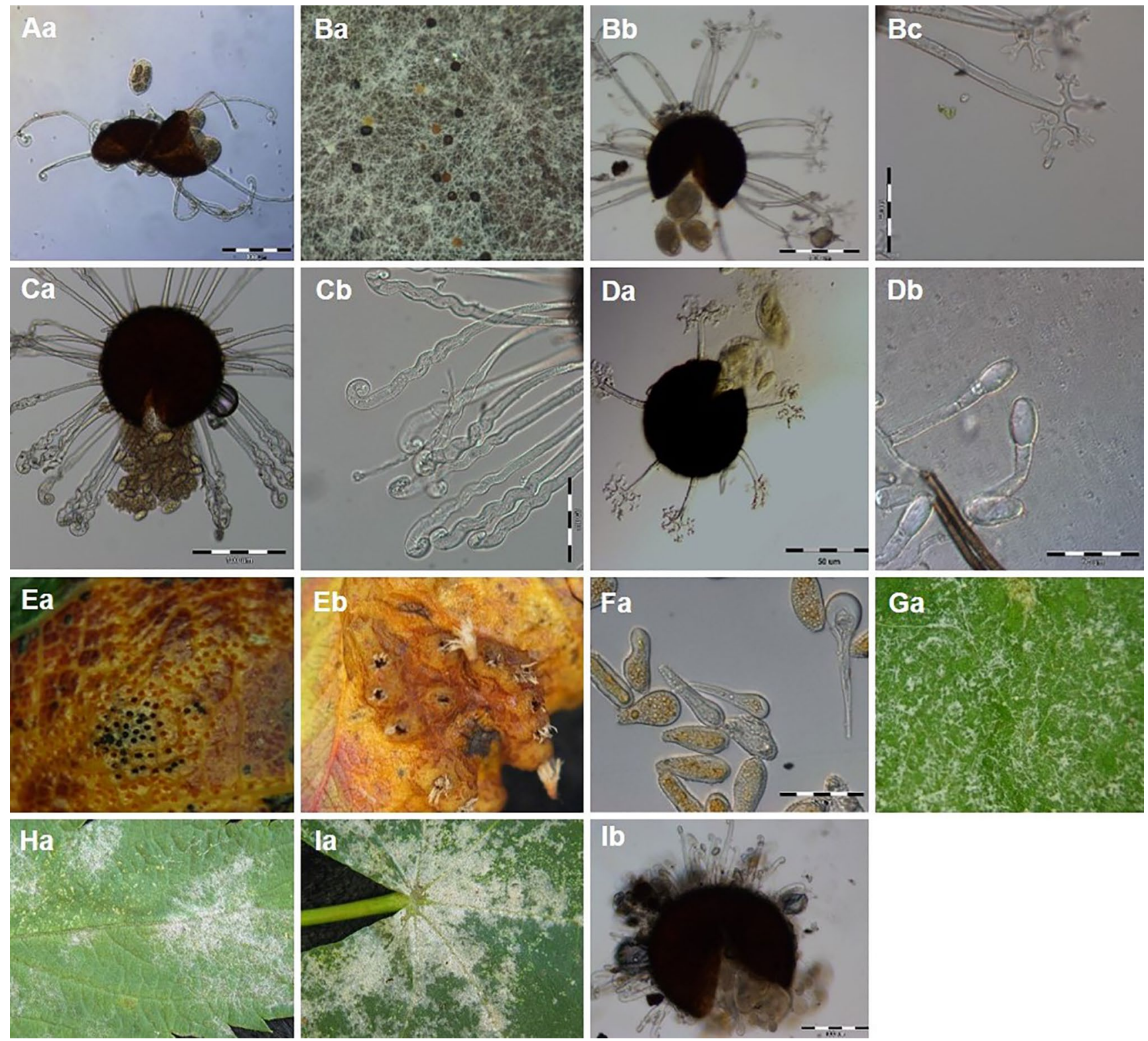

Fig. 2 Etiological signs of fungal pathogens observed during survey cross-referenced to the list of infected plants in Table 1. A Erysiphe adunca: Aa chasmothecium (on Populus nigra L.'Italica') (Phot. MŁ). B Erysiphe berberidis: Ba chasmothecia (Phot. EMM), Bb chasmothecium with asci (magnification) (Phot. MŁ), Bc appendages (magnification) (on Berberis vulgaris L.'Atropurpurea') (Phot. MŁ). C Erysiphe flexuosa: Ca chasmotecium (Phot. AB), Cb appendages (magnification) (on Aesculus hippocastanum) (Phot. AB). D Erysiphe magnifica: Da chasmotecium (Phot. JM), Db pseudoidium (on Mag- nolia sp.) (Phot. JM). E Gymnosporangium sabine: Ea spermogonia (Phot. EMM), Eb aecia (on Pyrus communis L.) (Phot. EMM). F Melampsora laricis-populina: Fa urediniospores (on Populus nigra L.'Italica') (Phot. MŁ). G Podosphaera leucotricha: Ga mycelium with conidial stage (on Malus sp.) (Phot. EMM). H Podosphaera sp.: Ha mycelium with conidial stage (on Spiraea japonica L.) (Phot. EMM). (Authors of photographs: Ewa Mirzwa-Mróz (EMM), students: Marta Łukaszewska (MŁ), Aleksandra Borkowska (AB), Justyna Muszyńska (JM))

E. alphitoides, i.e., the causal agent of powdery mildew identified on a $Q$. robur L. 'Fastigiata' tree was previously classified into the genus Microsphaera due to the structure of its teleomorph (the shape of appendages and the number of asci in chasmothecia). The morphological features of the pathogen were consistent with those reported in the literature 
(Braun and Cook 2012; Mieslerová et al. 2020). This powdery mildew was imported to Europe from North America and spread very quickly across the continent. In Poland, it is mainly a threat to oaks grown in nurseries (Mańka 2005). In the urban environment in Olsztyn, E. alphitoides was observed each year on mature and young $Q$. robur plants (Sucharzewska 2009). The fungus E. magnifica was observed on all magnolia trees growing in Square C. Infections of magnolias by this pathogen were also reported from Wales (Chater and Woods 2019) and Slovakia (Ondruskova et al. 2014).

Following the description provided by Braun (2011) and Braun and Cook (2012) related to E. berberidis identified on $B$. vulgaris 'Atropurpurea' plants, powdery mildew symptoms were observed on $B$. vulgaris 'Atropurpurea' plants analyzed in Poznan (Werner and Andrzejak 2008). Given the structure of appendages and the number of asci in the chasmothecium, this fungus was previously referred to as Microsphaera berberidis (Braun and Cook 2012). The pathogen was also observed on B. vulgaris in the Czech Republic (Mieslerová et al. 2020).

The fungus E. adunca was observed on all P. nigra 'Italica' trees in Square A. Its previous name was Uncinula adunca due to morphology of appendages and the number of asci in the chasmothecium (Braun and Cook 2012; Mieslerová et al. 2020). It is a common pathogen of the black poplar in Poland (Mułenko et al. 2008). The morphological features of this fungus were in line with the description provided by Braun and Cook (2012) and (Marcinkowska 2012).

Chestnut powdery mildew caused by E. flexuosa was identified in chestnut trees growing in Poland. This pathogen attacks both $A$. hippocastanum and A. x carnea (Piątek 2002; Zimmermannová-Pastircáková et al. 2002; Werner and Gołębniak 2010) and exhibits a clear preference for the latter host (Sucharzewska et al. 2018). In the present study, this pathogen was observed only on selected A. hippocastanum trees growing in Square B.

Apple scab caused by $V$. inaequalis (Pleosporales) which was identified according to Kochman (1986) and Marcinkowska (2012) on Malus x purpurea and other specimens of Malus sp. is one of the most dangerous diseases of those species (Bowen et al. 2011; Marcinkowska 2012), especially in areas where apples trees are grown commercially (MacHardy 1996; Bowen et al. 2011). As in the present study, a high prevalence of the disease was noted in Malus x purpurea in Poznan (Werner and Andrzejak 2008).

The fungus $G$. sabinae causing pear rust was identified on the basis of the structure of aecia and aeciospores (Majewski 1979; Marcinkowska 2012). The fungus which was noted on all pear trees in Square C, was also observed in Poland on various species representing the genera Pyrus and Juniperus by Werner and Gołębniak (2008). Only spermogonia and aecia were found to develop on the pear trees, as the pear is an intermediate host of pear rust. The thelia of this pathogen develop on its thelial host, i.e., Juniperus sabina L. (Kochman 1986; Marcinkowska 2012).

The rust fungus $M$. laricis-populina (Pucciniales) was noted on all black poplar trees growing in Square A. The morphology and average size of its urediniospores $(38.3 \times 14.5 \mu \mathrm{m})$ were characteristic for this species of rust (Klebahn 1902; Pei and McCracken 2005).

$P$. ostreatus which was detected on black poplars in Square A and Amur maples in Square C, was identified based on the structure of its fruiting body, i.e., the cap, hymenophore, and stipe. It is an edible fungus with fleshy annual shelving conks, sessile or with a short eccentric stalk (Pavlik and Pavlik 2013; Grzywacz and Staniszewski 2003; Szczepkowski 2012). P. ostreatus is a saprotrophic fungus accelerating wood decomposition (Pavlik 2005).

The fungus $R$. acerinum which was recognized on all $A$. platanoides trees growing in Square A, was also observed in green areas in Poznan as well (Werner and Andrzejak 2008). As shown by Łuszczyński (2002) and Kosiba (2007), the fungus can be used as an indicator of air pollution, as it is highly susceptible to the content of sulfur dioxide $\left(\mathrm{SO}_{2}\right)$ in the air. Since all the A. platanus trees showed symptoms of this disease, we can suppose that the air in the area of this Square is not polluted with $\mathrm{SO}_{2}$.

Compared to the observations made by the authors in previous years (unpublished data), relatively few cases of diseases of the trees and shrubs growing in the squares were observed in the 2017-2019 study. Most likely, this was related to the high temperatures recorded during the growing season and the long period of drought.

\section{Management recommendations}

Management of urban greenery is associated with the necessity to make a number of difficult and often costly decisions, as the maintenance of trees and shrubs is expensive. Additionally, progressive deterioration of the greenery health status and failure to maintain plant fitness are accompanied by an increase in financial expenditures (Nowak and Dwyer 2007). The deterioration of urban plant health caused by fungal diseases is a resultant of the combined effects of negative climate changes and human activity, and modifications of the natural environment contribute to faster growth of pathogens (Fisher et al. 2012). This tends to increase the expenses associated with the maintenance of green areas, and each financial decision must be justified (Hauer et al. 2015).

The management of urban greenery is a process that begins before planting and continues throughout plant life. The range of management activities that must be adjusted to the health status of trees and shrubs expands with the intensification of diseases, especially those caused by fungi. At every stage of plants' life (immature to semi-mature, mature, 
senescent), care treatments can significantly improve their health status, and thus increase the benefits of green areas to the city and its inhabitants (Vogt et al. 2015). In the case of fungal diseases, the recommended comprehensive management of greenery is based on solutions minimizing the spread and negative effects of infections caused by fungal pathogens. The main points of management recommendations are listed in Table 2.

\section{Conclusion}

The importance of trees and shrubs growing in urban green spaces, even in small green squares, is likely to increase in following years, given the benefits they bring to cities and their inhabitants. The negative phenomena related to climate change, resulting in the deterioration

Table 2 Management recommendations for trees and shrubs growing on green squares in Warsaw

\begin{tabular}{ll}
\hline Management aspect & Recommendations
\end{tabular}

Healthy plant material

Biodiversity and recommended plant species list

Plant maintenance

Treatment, removal, and disposal of host material

Systematic monitoring and control of fungal diseases

Research, education, and public awareness
Implementation of plants from high-quality nursery stock provided by local producers (International Plant Protection Convention and the World Trade Organization's Sanitary and Phytosanitary Standards Agreement adopted in 1951 (amended in 1997); Lilja et al. 1977; Benedikz et al. 2005; Tubby and Webber 2010)

The use of plant species diversity to limit the development of potential diseases (Hantsch et al.2014; Nielsen et al. 2014; Threlfall et al. 2017; Velásquez et al. 2018; Ampt et al. 2019);

Planting of native species as the basis of vegetation structures (Alvey 2006; Nielsen et al. 2014; Sjöman et al. 2016; Threlfall et al. 2017; Ampt et al. 2019; Conway et al. 2019);

Selection of plant species with higher tolerance to local pathogens and pests together with consideration of local abiotic stresses (Tello et al. 2005);

Recommendation of highly resistant plants in strategic documents for designs of urban greenery and replacement plantings (Tello et al. 2005)

Planting plants in a suitable location - trees or shrubs have a better chance of survival especially in the first years (Widney et al. 2016);

Nutrient management-supplementation of plant nutrients (Smiley et al. 2002; Brun et al. 2017);

fertilization can be supported by tree and shrub mulching (Ferrini et al. 2008; Fini and Ferrini 2011);

Mycorrhization of plants (Jung et al. 2012; Cameron et al. 2013; Szabó et al. 2014; Hui et al. 2017);

Watering especially during drought periods (Ferrini and Fini 2011; Jim 2019; Lüttge and Buckeridge 2020)

Reducing the occurrence of injuries-both mechanical ones and those resulting from undesirable behavior of the users of urban green areas (Tello et al. 2005);

minimum pruning and protection of each wound (Stagoll et al. 2012; Endreny 2018);

Replacement of removed infected plants with species or varieties more resistant to pathogens (Sosnowski et al. 2009);

Systematic removal of fallen infected parts of plants (Jain et al. 2019),

cleaning consistently and precisely the tools and machinery used (Jain et al. 2019),

Burning removed parts of infected plants outside the sites where they have been collected (Ebbels 2003; Downer et al. 2008; Jain et al. 2019);

Not using infected plant debris for the production of litter and composting (Anonymous 2008; Sosnowski et al. 2009);

Limitation of the use of chemicals to the necessary minimum and/or determination of their application rules by the local law (Lilja et al. 1977; Fini and Ferrini 2011)

Regular monitoring which facilitates quick detection and identification of fungal diseases (Jain et al. 2019), and registration of plant species most susceptible to pathogens;

The use of innovative tools for mapping and creating digital databases of pathogens (Zürcher 2017; Feltynowski et al. 2018)

Supporting the management processes by scientific research and implementation of its results directly into good practices; mutual interactions between science and practice are the basis of progress and improvement of the quality of the urban greenery (Jain et al. 2019; Jim 2019);

Raising public awareness of the necessity to maintain urban green areas in good condition and to eliminate unwanted behaviors (Tello et al. 2005; Collins et al. 2019);

Making efforts in the field of transfer of information and education related to diseases affecting urban plants between specialists and the society (Tello et al. 2005; Collins et al. 2019) 
of plants, may predispose trees and shrubs to the incidence of fungal diseases, which will further worsen their health. Such a scenario is confirmed by the results of the preliminary studies of fungal diseases affecting trees and shrubs growing in four squares in Warsaw carried out in 2017-2019. These investigations were conducted in very warm and dry spring and summer periods. Although the conditions were unfavorable for the spread of pathogens, Sawadaea tulasnei, S. bicornis, Podosphaera leucotricha, Podosphaera sp., Erysiphe alphitoides, E. magnifica, E. berberidis, E. flexuosa and E. adunca (causal agents of powdery mildew), Gymnosporangium sabinae, Melampsora laricis-populina (rusts), Venturia inaequalis (apple scab), Rhytisma acerinum (tar spot of maple), and Pleurotus ostreatus (oyster mushroom) were identified. They are common fungal pathogens in these urban green areas.

However, they had substantially lower intensity than in typical years and attacked a smaller number of trees. Favorable conditions promoting the development of fungal diseases may support faster growth and spread of pathogens, which in turn will become a major threat to plant health. Therefore, it is necessary to continue and expand research aimed at diagnosis of fungal diseases on trees and shrubs in urban green areas to ensure early identification of emerging threats posed by fungal pathogens and to take comprehensive measures to eliminate these disease causal agents. Protection of plant health against the effects of fungal diseases requires conscious management of urban greenery. The formulation of guidelines based on the good practice of multifaceted plant monitoring and application of the recommendations in a comprehensive and sustainable strategy for counteracting fungal diseases will help to preserve more healthy trees and shrubs in urban green squares and other green areas.

\section{Author contribution statement KK, EMM and MSS con-} tributed to the conception and design of the study. Plant inventory in selected green squares was conducted by KK. Recognition of fungal diseases symptoms on plants during site visits were performed by EMM and MSS. Plant materials collection and selected photographic documentation of pathogens were taken by students under the supervision of EMM and MSS. Data analysis was performed by all authors. Literature review and recommendations were performed and developed by KK, and supplemented by EMM and MSS. The first draft of the manuscript was written by KK and developed together with EMM and MSS. All authors read and commented the manuscript.

Funding The research presented in this paper has no funding support.
Data availability All authors declare that the data presented in paper belong to authors.

Code availability Not applicable.

\section{Declarations}

Conflicts of interest All authors of the paper declare that there are no conflicts of interest.

Additional declarations for articles in life science journals that report the results of studies involving humans and/or animals Not applicable.

Ethics approval Not applicable.

Consent to participate Not applicable.

Consent for publication Not applicable.

Open Access This article is licensed under a Creative Commons Attribution 4.0 International License, which permits use, sharing, adaptation, distribution and reproduction in any medium or format, as long as you give appropriate credit to the original author(s) and the source, provide a link to the Creative Commons licence, and indicate if changes were made. The images or other third party material in this article are included in the article's Creative Commons licence, unless indicated otherwise in a credit line to the material. If material is not included in the article's Creative Commons licence and your intended use is not permitted by statutory regulation or exceeds the permitted use, you will need to obtain permission directly from the copyright holder. To view a copy of this licence, visit http://creativecommons.org/licenses/by/4.0/.

\section{References}

Aitken SN, Yeaman S, Holliday JA, Wang T, Curtis-McLane S (2008) Adaptation, migration or extirpation: climate change outcomes for tree populations. Evol Appl 1(1):95-111. https://doi.org/10. 1111/j.1752-4571.2007.00013.x

Aldous DE (2007) Social, environmental, economic, and health benefits of green spaces. In: Lumpkin TA, Warrington IJ (ed) Proceedings of the International Symposium on Horticultural Plants in Urban and Peri-Urban Life. Acta Hortic 762:171-185. https:// doi.org/10.17660/ActaHortic.2007.762.17

Alvey AA (2006) Promoting and preserving biodiversity in the urban forest. Urban for Urban Greening 5(4):195-201. https://doi.org/ 10.1016/j.ufug.2006.09.003

Ampt EA, van Ruijven J, Raaijmakers JM, Termorshuizen AJ, Mommer L (2019) Linking ecology and plant pathology to unravel the importance of soil-borne fungal pathogens in species-rich grasslands. Eur J Plant Pathol 154:141-156. https://doi.org/10. 1007/s10658-018-1573-x

Anonymous (2008) Guidelines for the management of plant health risks of biowaste of plant origin. PM 3/66 (2). EPPO Bulletin 38:4-9. https://doi.org/10.1111/j.1365-2338.2008.01167.x

Baur JWR (2018) Urban green spaces, recreation and spiritual experiences. Leisure/loisir 42(2):205-229. https://doi.org/10.1080/ 14927713.2018.1449131

Baur JWR, Tynon JF (2010) Small-scale urban nature parks: Why should we care? Leisure Sci 32(2):195-200. https://doi.org/10. 1080/01490400903547245 
Benedikz T, Ferrini F, Garcia-Valdecantos JL, Tello ML (2005) Plant Quality and Establishment. In: Konijnendijk C, Nilsson K, Randrup T, Schipperijn J (ed) Urban Forests and Trees. Springer, Berlin, Heidelberg. https://doi.org/10.1007/3-540-27684-X_10

Berman MG, Kross E, Krpan KM, Askren MK, Burson A, Deldin PJ, Kaplan S, Sherdell L, Gotlib ICH, Jonides J (2012) Interacting with nature improves cognition and affect for individuals with depression. J Affect Disord 140(3):300-305. https://doi.org/10. 1016/j.jad.2012.03.012

Berto R (2014) The role of nature in coping with psycho-physiological stress: a literature review on restorativeness. Behav Sci 4(4):394409. https://doi.org/10.3390/bs4040394

Bowen JK, Mesarich CH, Bus VGM, Beresford RM, Plummer KM, Templeton MD (2011) Venturia inaequalis: the causal agent of apple scab. Mol Plant Pathol 12(2):105-122. https://doi.org/ 10.1111/j.1364-3703.2010.00656.x

Bowler DE, Buyung-Ali LM, Knight TM, Pullin AS (2010) A systematic review of evidence for the added benefits to health of exposure to natural environments. BMC Public Health 10:456. https://doi.org/10.1186/1471-2458-10-456

Braun U (2011) The current systematics and taxonomy of the powdery mildews (Erysiphales): an overview. Mycoscience 52(3):210-212. https://doi.org/10.1007/S10267-010-0092-1

Braun U, Cook RTA (2012) Taxonomic manual of the Erysiphales (Powdery Mildews), CBS Biodiversity Series 11. Centraalbureau voor Schimmelcultures, Utrecht, The Netherlands

Brun FGK, Brun EJ, Gerber D, Szymczak DA, Londero EK, Meyer EA, Navroski MC (2017) Nutrition facts and limits for micronutrients in tree species used in urban forestry. An Acad Bras Ciênc 89(3):1881-1893. https://doi.org/10.1590/0001-37652 01720160785

Cameron DD, Neal AL, van Wees SCM, Ton J (2013) Mycorrhizainduced resistance: more than the sum of its parts? Trends Plant Sci 18:539-545. https://doi.org/10.1016/j.tplants.2013. 06.004

Chater AO, Woods RG (2019) The Powdery Mildews (Erysiphales) of Wales: an identification guide and census catalogue. A.O. Chater (Privately Published), Aberystwyth

Chen WY, Jim CY (2008) Assessment and Valuation of the Ecosystem Services Provided by Urban Forests. In: Carreiro MM, Song YC, Wu J (ed) Ecology, Planning, and Management of Urban Forests. Springer, New York, pp 53-83. https://doi.org/10.1007/ 978-0-387-71425-7_5

Cimanowski J (1969) Epidemiologia mączniaka jabłoniowego Podosphaera leucotricha (Ell. et Ev.) Salm. w Polsce [Epidemiology of apple mildew Podosphaera leucotricha (Ell. et Ev.) Salm. in Poland]. Acta Agrobot XXII(2):253-263

Collins C, Cook-Monie I, Raum S (2019) What do people know? Ecosystem services, public perception and sustainable management of urban park trees in London, U.K.Urban For Urban Greening 43:126362 https://doi.org/10.1016/j.ufug.2019.06.005

Conway TM, Almas AD, Chore D (2019) Ecosystem services, ecological integrity, and native species planting: How to balance these ideas in urban forest management? Urban for Urban Greening 41:1-5. https://doi.org/10.1016/j.ufug.2019.03.006

Dolatowski J, Seneta W (2009) Dendrologia [Dendrology]. Wydawnictwo Naukowe PWN, Warszawa

Donovan GH (2017) Including public-health benefits of trees in urbanforestry decision making. Urban for Urban Greening 22:120123. https://doi.org/10.1016/j.ufug.2017.02.010

Downer AJ, Crohn D, Faber B, Daugovish O, Becker JO, Menge JA, Mochizuki MJ (2008) Survival of plant pathogens in static piles of ground green waste. Phytopathology 98:574-554. https://doi. org/10.1094/PHYTO-98-5-0547
Dynowska M, Fiedorowicz G, Kubiak D (1999) Contribution to the distribution of Erysiphales in Poland. Acta Mycol 34:79-88. https://doi.org/10.5586/am.1999.006

Dziubiak M (2007) Gatunki jabłoni w zbiorach Ogrodu Botanicznego-Centrum Zachowania Różnorodności Biologicznej PAN w Warszawie [Malus species in collections of the Botanical Garden - Center for Biological Diversity Conservation, Polish Academy of Sciences in Warsaw]. Zeszyty Problemowe Postępów Nauk Rolniczych 517(1):43-51

Ebbels DL (2003) Principles of plant health and quarantine. CABI Publishing, Wallingford

Endreny TA (2018) Strategically growing the urban forest will improve our world. Nat Commun 9:1160. https://doi.org/10.1038/ s41467-018-03622-0

Feltynowski M, Kronenberg J, Bergier T, Kabisch N, Łaszkiewicz E, Strohbach MW (2018) Challenges of urban green space management in the face of using inadequate data. Urban for Urban Greening 31:56-66. https://doi.org/10.1016/j.ufug.2017.12.003

Ferrini F, Fini A (2011) Sustainable management techniques for trees in the urban areas. JBES 1(1):1-20. http://jbes.ir/wp-content/ docs/vol1/1/1.pdf

Ferrini F, Fini A, Frangi P, Amoroso G (2008) Mulching of ornamental trees: effects on growth and physiology. Arboriculture \& Urban Forestry 34(3):157-162. https://core.ac.uk/download/pdf/30156 0359.pdf

Fini A, Ferrini F (2011). Effects of mulching with compost on growth and physiology of Acer campestre L. and Carpinus betulus $\mathrm{L}$. Advances in Horticultural Science 25(4):232-238. https://www. jstor.org/stable/42883569

Fisher MC, Henk DA, Briggs CJ, Brownstein JS, Madoff LC, McCraw SL, Gurr SJ (2012) Emerging fungal threats to animal, plant and ecosystem health. Nature 484(7393):186-194. https://doi.org/10. 1038/nature 10947

Grahn P, Stigsdotter UK (2010) The relation between perceived sensory dimensions of urban green space and stress restoration. Landsc Urban Plan 94:264-275. https://doi.org/10.1016/j.landu rbplan.2009.10.012

Grzywacz A, Staniszewski P (2003) Wiem co zbieram w lesie [I know what I am collecting in the forest]. Oficyna Wydawnicza Multico, Warszawa

Hantsch L, Bien S, Radatz S, Braun U, Auge H, Bruelheide H (2014) Tree diversity and the role of non-host neighbour tree species in reducing fungal pathogen infestation. J Ecol 102(6):1673-1687. https://doi.org/10.1111/1365-2745.12317

Hauer RJ, Vogt JM, Fischer BC (2015) The cost of not maintaining the urban forest. Arborist News 24(1):12-17

Hausmann SL, Petermann JS, Rolff J (2016) Wild bees as pollinators of city trees. Insect Conserv Diversity 9(2):97-107. https://doi. org/10.1111/icad.12145

Heluta VP, Dzhagan VV, Senchylo OO (2016) First records of a powdery mildew fungus Sawadaea bicornis (wallr.) Homma on Acer velutinum Boiss. in Ukraine. Інтродукція рослин 1:64-69

Hui N, Liu X, Kotze DJ, Jumpponen A, Francini G, Setälä H (2017) Ectomycorrhizal fungal communities in urban parks are similar to those in natural forests but shaped by vegetation and park age. Appl Environ Microbiol 83:e01797-e1817. https://doi.org/10. 1128/AEM.01797-17

Index Fungorum. www.indexfungorum.org Accessed 10 September 2017 and 20 November 2020

Jain A, Sarsaiya S, Wu Q, Lu Y, Shi J (2019) A review of plant leaf fungal diseases and its environment speciation. Bioengineered 10(1):409-424. https://doi.org/10.1080/21655979.2019.1649520

Jim CY (2019) Resolving intractable soil constraints in urban forestry through research - practice synergy. Socio Ecol Pract Res 1:4153. https://doi.org/10.1007/s42532-018-00005-z 
Johnston M, Hirons A (2014) Urban trees. In: Dixon G, Aldous D (ed) Horticulture: plants for people and places, Vol. 2. Springer, Dordrecht, pp. 693-711. https://doi.org/10.1007/ 978-94-017-8581-5_5

Jung SC, Martinez-Medina A, Lopez-Raez JA, Pozo MJ (2012) Mycorrhiza-induced resistance and priming of plant defenses. J Chem Ecol 38:651-664. https://doi.org/10.1007/s10886-012-0134-6

Karade RM, Kuchi VS, Kabir J (2017) The role of green space for sustainable landscape development in urban areas. Acta Hortic 1181:73-76. https://doi.org/10.17660/ActaHortic.2017.1181.9

Kazmierczak A (2013) The contribution of local parks to neighbourhood social ties. Landsc Urb Plan 109(1):31-44. https://doi.org/ 10.1016/j.landurbplan.2012.05.007

Kimic K (2021) Pear trees (Pyrus communis L.) as monuments of nature in Warsaw public spaces - state of preservation. In: Fialová J (ed) Public recreation and landscape protection-with sense hand in hand! Conference proceedings, 10th-11th May 2021, Krrtiny. Mendel University in Brno, Brno, pp 349-353

Kimic K (2019) Sad jako element szczególny parku miejskiego-historia i współczesność [Orchard as a special element of an urban park - history and the present]. Teka Komisji Architektury i Urbanistyki [Urbanity and Architecture Files] XLVII:163-174. https://doi.org/10.24425/tkuia.2019.131172

Klebahn H (1902) Kulturversuche mit Rostpilzen. Kulturversuche mit Rostpilzen, X. Bericht, Zeitschrift für Pflanzenkrankheiten 12:17-44. https://www.biodiversitylibrary.org/page/15447375\# page/1/mode/1up Accessed 12 August 2020

Kochman J (1960) O nowych dla Polski mączniakach prawdziwych [New to Poland Peronospora]. Acta Agrobotanica IX(2):89-97

Kochman J (1986) Zarys mikologii dla fitopatologów [Outline of mycology for phytopathologists]. Wydawictwo SGGW-AR, Warszawa

Koeser AK, Vogt J, Hauer RJ, Northrop RJ, Peterson W (2016) The Cost of Not Maintaining trees: findings and recommendations from an international symposium and summie. Arboric Urban for 42(6):377-388

Kosiba P (2007) Impact of air pollution on the occurrence of Rhytisma acerinum "tar-spot" on maple leaves. Acta Soc Bot Pol 76(4):333-343

Kowarik I (2011) Novel urban ecosystems, biodiversity, and conservation. Environ Pollut 159:1974-1983. https://doi.org/10.1016/j. envpol.2011.02.022

Kuo M (2015) How might contact with nature promote human health? Promising mechanisms and a possible central pathway. Front Psychol 6:1093. https://doi.org/10.3389/fpsyg.2015.01093

Lilja A, Lilja S, Kurkela T, Rikala R (1977) Nursery practices and management of fungal diseases in forest nurseries in finland: a review. Silva Fennica 31(1):79-100

Lisandru TT, Kimic K, Mitre V (2016) Identification of Fruit Tree Compositions in Public Parks Structure. Warsaw Case Study. Bulletin UASVM Horticulture 73(2):156-162. https://doi.org/ 10.15835/buasvmcn-hort:12236

Livesley SJ, McPherson EG, Calfapietra C (2016) The Urban forest and ecosystem services: impacts on urban water, heat, and pollution cycles at the tree, street, and city scale. J Environ Qual 45(1):119-124. https://doi.org/10.2134/jeq2015.01.0056

Łuszczyński J (2002) Możliwości i sposoby wykorzystania grzybów w monitoringu środowiska [Possibilities and ways of using fungi in environmental monitoring]. Regionalny Monitoring Środowiska Przyrodniczego 3:53-55. Kieleckie Towarzystwo Naukowe, Kielce

Lüttge U, Buckeridge M (2020) Trees: structure and function and the challenges of urbanization. Trees. https://doi.org/10.1007/ s00468-020-01964-1
MacHardy WE (1996) Apple Scab: Biology, Epidemiology, and Management. St. Paul, MN, USA, APS.

Majewski T (1977) Grzyby [Mycota] 9: Basidiomycetes, Uredinales. I. PWN, Warszawa-Kraków

Majewski T (1979) Grzyby [Mycota] 11: Basidiomycetes, Uredinales. II. PWN, Warszawa-Kraków

Mańka K (2005) Fitopatologia leśna [Forest phytopathology]. PWRiL, Warszawa

Marçais B, Desprez-Loustau ML (2014) European oak powdery mildew: impact on trees, effects of environmental factors, and potential effects of climate change. Ann for Sci 71:633-642. https:// doi.org/10.1007/s13595-012-0252-x

Marcinkowska J (2012) Oznaczanie rodzajów grzybów sensu lato ważnych w fitopatologii [Identification of fungi genera sensu lato important in phytopathology]. PWRiL, Warszawa

Mieslerová B, Sedlářová M, Michutová M, Petřeková V, Cook R, Lebeda A (2020) Powdery Mildews on Trees and Shrubs in Botanical Gardens, Parks and Urban Green Areas in the Czech Republic. Forests 11:967. https://doi.org/10.3390/f11090967

Mułenko W, Majewski T, Ruszkiewicz-Michalska M (2008) Wstępna lista grzybów mikroskopijnych Polski [A preliminary checklist of micromycetes in Poland]. W. Szafer Institute of Botany, PAN, Kraków

Mycobank. https://www.mycobank.org. Accessed 12 September 2017 and 20 November 2020

Ngiam RWJ, Lim WL, Collins CM (2017) A balancing act in urban social-ecology: human appreciation, ponds and dragonflies. Urban Ecosyst 20(4):743-758. https://doi.org/10.1007/ s11252-016-0635-0

Nielsen AB, van den Bosch M, Maruthaveeran S, van den Bosch CK (2014) Species richness in urban parks and its drivers: a review of empirical evidence. Urban Ecosyst 17:305327. https://doi.org/ 10.1007/s11252-013-0316-1

Nowak DJ, Dwyer JF (2007) Understanding the Benefits and Costs of Urban Forest Ecosystems. In: Kuser JE (ed) Urban and Community Forestry in the Northeast. Springer, Dordrecht, pp 11-25. https://doi.org/10.1007/978-1-4020-4289-8_2

Ondruskova E, Juhásová G, Pastircakova K (2014) The lily magnolia powdery mildew Erysiphe magnifica found in Slovakia. Mycotaxon-Ithaca Ny 127(1):51-57

Pavlik M (2005) Growing of Pleurotus ostreatus on woods of various deciduous trees. Acta Edulis Fungi 12:306-312

Pavlik M, Pavlik S (2013) Wood decomposition activity of oyster mushroom (Pleurotus ostreatus) isolate in situ. J For Sci 59(1):28-33. https://doi.org/10.17221/60/2012-JFS

Pearlmutter D, Calfapietra C, Samson R, O'Brien L, Ostoić SK, Sanesi G, del Amo RA (2017) The Urban forest: cultivating green infrastructure for people and the environment. Springer International Publishing AG, Cham, Switzerland

Pei MH, McCracken AR (2005) Rust diseases of willow and poplar. CABI Publishing, Wallingford, Oxon

Peschardt KK, Schipperijn J, Stigsdotter UK (2012) Use of small public urban green spaces (SPUGS). Urban for Urban Greening 11:235244. https://doi.org/10.1016/j.ufug.2012.04.002

Piątek M (2002) Erysiphe flexuosa, a new for Poland powdery mildew causing disease of Aesculus hippocastanum. Phytopathologia 24:67-71

Schlaepfer MA (2018) Do non-native species contribute to biodiversity? PLoS Biol 16(4):e2005568. https://doi.org/10.1371/journ al.pbio. 2005568

Schlaepfer MA, Guinaudeau BP, Martin P, Wyler N (2020) Quantifying the contributions of native and non-native trees to a city's biodiversity and ecosystem services. Urban for Urban Greening 56:126861. https://doi.org/10.1016/j.ufug.2020.126861 
Seth MK (2003) Trees and their economic importance. Bot Rev 69:321-376. https://doi.org/10.1663/0006-8101(2004)069[0321: TATEI]2.0.CO;2

Shanahan DF, Lin BB, Gaston KJ et al (2015) What is the role of trees and remnant vegetation in attracting people to urban parks? Landscape Ecol 30:153-165. https://doi.org/10.1007/ s10980-014-0113-0

Shi W, Woolley H (2014) Managing for multifunctionality in Urban open spaces: approaches for sustainable development. J Urban Manag 3(1-2):3-21. https://doi.org/10.1016/S2226-5856(18) 30081-5

Sjöman H, Morgenroth J, Sjöman JD, Sæbø A, Kowarik I (2016) Diversification of the urban forest-Can we afford to exclude exotic tree species? Urban for Urban Green 18:237-241. https://doi.org/ 10.1016/j.ufug.2016.06.011

Smiley ET, Lilly SJ, Kelsey P (2002) Best management practices: tree and shrub fertilization. International Society of Arboriculture, Champaign

Sosnowski MR, Fletcher JD, Daly AM, Rodoni BC, Viljanen-Rollinson SLH (2009) Techniques for the treatment, removal and disposal of host material during programmes for plant pathogen eradication. Plant Pathol 58(4):621-635. https://doi.org/10.1111/j.13653059.2009.02042.x

Standardy Kształtowania Zieleni Warszawy [Warsaw Greenery Standards] (2016). https://bip.warszawa.pl/NR/rdonlyres/0012d003/ vxkmgrptdbnredpqifeqbborigwphleo/Za\%C5\%82acznik7doPo\% C5\%9BStandardy.pdf Accessed 16 October 2020

Stagoll K, Lindenmayer DB, Knight E, Fischer J, Manning AD (2012) Large trees are keystone structures in urban parks. Conserv Lett 5(2):115-122. https://doi.org/10.1111/j.1755-263X.2011. 00216.x

Sucharzewska E (2010) Key survival strategies of the Sawadaea tulasnei parasite on its Acer platanoides host under conditions of varied anthropopression. Pol J Environ Stud 19(5):1013-1017

Sucharzewska E, Kulesza K, Ejdys E, Dynowska M, Kubiak D, Biedunkiewicz A (2018) Erysiphe Flexuosa (Fungi, Erysiphales) - Life strategies and threats to Chestnut trees including Cameraria Ohridella (Lepidoptera, Gracillariidae) pest in the urban environment. Pol J Natur Sc 33(2):233-246

Sucharzewska E (2009) The development of Erysiphe alphitoides and E. hypophylla in the urban environment. Acta Mycol 44(1):109-123

Suchocka M, Kimic K (2019) Management of urban forest to ensure the safety of touristic use on the example of Warsaw. In: Fialová J (ed) Public recreation and landscape protection - with sense hand in hand! Conference proceeding, 13th-15th May 2019, Krrtiny. Mendel University in Brno, Brno, pp 236-239

Szabó K, Böll S, Zs E-H (2014) Applying artificial mycorrhizae in planting urban trees. Appl Ecol Environ Res 12(4):835-853. https://doi.org/10.1111/j.1365-3059.2009.02042.x

Szczepkowski A (2012) Grzyby nadrzewne w innym świetleużytkowanie owocników [Arboreal fungi in a different lightthe use of sporocarps]. Studia i Materiały CEPL w Rogowie 14/32(3):171-189

Tello ML, Tomalak M, Siwecki R, Gáper J, Motta E, Mateo-Sagasta E (2005) Biotic Urban Growing Conditions-Threats, Pests and Diseases. In: Konijnendijk C, Nilsson K, Randrup T, Schipperijn J. (ed) Urban Forests and Trees. Springer, Berlin, Heidelberg. https://doi.org/10.1007/3-540-27684-X_13

Threlfall CG, Mata L, Mackie JA, Hahs AK, Stork NE, Williams NSG, Livesley SJ (2017) Increasing biodiversity in urban green spaces through simple vegetation interventions. J Appl Ecol 54:18741883. https://doi.org/10.1111/1365-2664.12876

Troy A, Nunery A, Grove JM (2016) The relationship between residential yard management and neighborhood crime: an analysis from
Baltimore City and County. Landsc Urb Plan 147:78-87. https:// doi.org/10.1016/j.landurbplan.2015.11.004

Tubby KV, Webber JF (2010) Pests and diseases threatening urban trees under a changing climate. Forestry 83(4):451-459. https://doi. org/10.1093/forestry/cpq027

Turner-Skoff JB, Cavender N (2019) The benefits of trees for livable and sustainable communities. Plants People Planet 1:323-335. https://doi.org/10.1002/ppp3.39

Tyrväinen L, Pauleit S, Seeland K, de Vries S (2005) Benefits and Uses of Urban Forests and Trees. In: Konijnendijk C, Nilsson K, Randrup T, Schipperijn J (ed) Urban Forests and Trees. Springer, Berlin, Heidelberg, pp 81-114. https://doi.org/10. 1007/3-540-27684-X_5

Tzoulas K, Korpela K, Venn S, Yli-Pelkonen V, Kazmierczak A, Niemela J, James P (2007) Promoting ecosystem and human health in urban areas using green infrastructure: a literature review. Landsc Urb Plan 81(3):167-178. https://doi.org/10.1016/j.landu rbplan.2007.02.001

Ulrich RS, Simons RF, Losito BD, Fiorito E, Miles MA, Zelson M (1991) Stress recovery during exposure to natural and urban environments. J Environ Psychol 11(3):201-230. https://doi.org/10. 1016/S0272-4944(05)80184-7

Velásquez AC, Castroverde C, He SY (2018) Plant-pathogen warfare under changing climate conditions. Curr Biol 28(10):R619R634. https://doi.org/10.1016/j.cub.2018.03.054

Vogt JM, Hauer RJ, Fischer BC (2015) The cost of maintaining and not maintaining the Urban forest: a review of the Urban forestry and arboriculture literature. Arboriculture Urban Forestry 41(6):293-323

Werbin ZR, Heidari L, Buckley S, Brochu P, Butler LJ, Connolly C, Bloemendaal LH, McCabe TD, Miller TK, Hutyra LR (2020) A treeplanting decision support tool for urban heat mitigation. PLoS ONE 15(10):e0224959. https://doi.org/10.1371/journal. pone. 0224959

Werner M, Andrzejak R (2008) Patogeny obniżające wartości dekoracyjne drzew i krzewów terenów zieleni miasta Poznania [Pathogens devastating trees and shrubs on green areas of the Poznań city]. Zeszyty Problemowe Postępów Nauk Rolniczych 529:235-247

Werner M, Gołębniak B (2008) Występowanie, szkodliwość i rozwój rdzy gruszy (Gymnosporangium sabinae) [Occurrence, harmfulness and development of the pear rust (Gymnosporagium sabinae)]. Zeszyty Problemowe Postępów Nauk Rolniczych 529:249-256

Werner M, Gołębniak B (2010) Nowe patogeny na drzewach i krzewach parkowych—rozprzestrzenienie i szkodliwość [New pathogens on park trees and shrubs—-spread and harmfulness]. Zeszyty Problemowe Postępów Nauk Rolniczych 554:285-293

Widney S, Fischer BC, Vogt J (2016) Tree mortality undercuts ability of tree-planting programs to provide benefits: results of a threecity study. Forests 7(3):65. https://doi.org/10.3390/f7030065

Wolf KL, Lam ST, McKeen JK, Richardson G, van den Bosch M, Bardekjian AC (2020) Urban trees and human health: a scoping review. Int J Environ Res Public Health 17(12):4371. https://doi. org/10.3390/ijerph17124371

Wysmułek J, Hełdak M, Kucher A (2020) The analysis of green areas' accessibility in comparison with statistical data in Poland. Int $\mathbf{J}$ Environ Res Public Health 17(12):4492. https://doi.org/10.3390/ ijerph17124492

Zimmermannová-Pastircáková K, Adamska I, Blaszkowski J, Bolay A, Braun U (2002) Epidemic spread of Erysiphe flexuosa (North American powdery mildew of horse-chestnut) in Europe. Schlechtendalia 8:39-45

Zölch T, Rahman MA, Pfleiderer E, Wagner G, Pauleit S (2019) Designing public squares with green infrastructure to optimize 
human thermal comfort. Build Environ 149:640-654. https://doi. org/10.1016/j.buildenv.2018.12.051

Zürcher N (2017) Assessing the Ecosystem Services Deliverable: The Critical Role of the Urban Tree Inventory. In: Pearlmutter D, Calfapietra C, Samson R, O'Brien L, Krajter Ostoić S, Sanesi G, del Amo RA (ed) The Urban Forest. Future City, vol 7. Springer, Cham, pp 101-110. https://doi.org/10.1007/978-3-319-50280-9_ 11
Publisher's Note Springer Nature remains neutral with regard to jurisdictional claims in published maps and institutional affiliations. 